\title{
Eesti ja vene õppekeelega põhikooliõpilaste akadeemiline läbipõlemine
}

\author{
Kati Vinter ${ }^{\mathrm{a} 1}$, Kati Aus ${ }^{\mathrm{a}}$, Grete Arro ${ }^{\mathrm{a}}$ \\ a Tallinna Ülikooli haridusteaduste instituut
}

\begin{abstract}
Annotatsioon
Uuringu eesmärk on analüüsida erinevusi eesti ja vene óppekeelega õpilaste akadeemilises läbipõlemises ning akadeemilise läbipõlemise seoseid erinevate kognitiivsete (matemaatikaoskused ja üldvõimekus) ja sotsiaal-kognitiivsete teguritega (arenguuskumused ja akadeemiline psühholoogiline säilenõtkus). Uuringus osales 429 kaheksanda klassi õpilast viiest vene $(n=174)$ ja seitsmest eesti $(n=255)$ õppekeelega Tallinna koolist. Tulemustest selgus, et läbipõlemise tase oli eri õppekeelega õpilastel sarnane. Kognitiivsed tegurid ei seostunud läbipõlemisega kummaski rühmas, kuid sotsiaal-kognitiivsed tegurid, kalduvus jäävususkumustele ja madal säilenõtkuse tase olid läbipõlemisega seotud mõlemas rühmas. Samuti ilmnes, et eesti õpilaste hulgas olid läbipõlemisele altimad madala säilenõtkuse taseme ja paremate matemaatikaoskustega õpilased. Edasistes uurimustes võiks keskenduda võimalustele, kuidas arendada nii arenguuskumuste kui ka säilenõtkusega seotud teadmisi ja oskusi.
\end{abstract}

Võtmesõnad: akadeemiline läbipõlemine, matemaatikaoskused, üldvõimekus, arenguuskumused, akadeemiline psühholoogiline säilenõtkus, eesti ja vene õppekeel

\section{Sissejuhatus}

Hariduspoliitikat suunavates dokumentides ja uuringutes nii Euroopa Liidu (Council Recommendation, 2018; OECD, 2017, 2018) kui ka riiklikul (Eesti elukestva õppe ..., 2014) tasandil rõhutatakse aina enam, et peale heade akadeemiliste oskuste kujundamise on hariduse ülesanne suunata psühholoogilist heaolu toetavate oskuste arengut. Selle saavutamiseks on esitatud Eesti põhikooli riiklikus õppekavas (2018) aineteülesed üldpädevused. Ka enesereguleeritud õppimise teoreetilistes raamistikes rõhutatakse kognitiivseid,

Haridusteaduste instituut, Tallinna Ülikool, Narva mnt 25, 10120 Tallinn; kati.vinter@tlu.ee 
metakognitiivseid, käitumuslikke, motivatsioonilisi ja sotsiaal-emotsionaalseid aspekte, mis aitavad kujundada selliseid õppijaid, kes juhivad nii oma õppimist kui ka subjektiivset heaolu (vt nt Boekaerts \& Niemivirta, 2000; Efklides, 2011; Pintrich, 2000; Zimmerman, 2000; ülevaatlikult vt ka Panadero, 2017).

Heaolu ja selle juhtimisega seotud tegurite olulisusele annab kinnitust ka tõsiasi, et heaolu on üks akadeemiliste oskuste (nt Buecker, Nuraydin, Simonsmeier, Schneider, \& Luhmann, 2018) ning haridussüsteemis püsimise alustalasid (Bask \& Salmela-Aro, 2013). On leitud, et isiklik heaolu ennustab oluliselt nii õpilaste isiklikku arengut kui ka akadeemilist edukust (Yu, Shek, \& Zhu, 2018). Korduvad negatiivsed emotsioonid ja stressi kogemine teismeeas ning napid oskused nendega toime tulla seostuvad kehvema psühholoogilise heaoluga (Garnefski, Legerstee, Kraaij, van den Kommer, \& Teerds, 2002) ning tõenäoliselt ka halvema kohanemisega hilisemas elus.

Kehvem psühholoogiline heaolu võib väljenduda õpilaste akadeemilise läbipõlemisena (Salmela-Aro, Savolainen, \& Holopainen, 2009), mida on teismeliste hulgas seostatud nii halvemate õpitulemusega (Salmela-Aro, Kiuru, \& Jokela, 2008; Salmela-Aro, Savolainen et al., 2009) kui ka koolist väljalangemisega (Bask \& Salmela-Aro, 2013). Enamik noori tuleb teismeeaga toime ilma suurte emotsionaalsete probleemideta, kuid siiski on paljud selle eluetapi üleminekute ja muutustega kohanemisel raskustes (Blackwell, Trzesniewski, \& Dweck, 2007; Salmela-Aro, Savolainen et al., 2009). Seetõttu on oluline uurida, millised võivad olla heaolu vähenemise tagamaad just teismeliste puhul, ning muu hulgas juhtida tähelepanu ka läbipõlemist ennustavatele riskiteguritele. Siinses uurimuses oleme võtnud eesmärgiks analüüsida, kuidas on eesti ja vene õppekeelega 8. klassi õpilaste akadeemilise läbipõlemisega seotud õpilaste kognitiivsed tegurid (matemaatikaoskused ja üldvõimekus) ning toimetulekut soodustavad või pärssivad sotsiaal-kognitiivsed tegurid (arenguuskumused ja akadeemiline psühholoogiline säilenõtkus).

\section{Uurimuse teoreetilised lähtekohad}

\section{Akadeemiline läbipõlemine}

Läbipõlemist (burnout) on defineeritud kui emotsionaalse kurnatuse, küünilisuse ja vähenenud saavutusvõime sündroomi (Maslach \& Jackson, 1981). Kuigi läbipõlemist seostati alguses vaid töökeskkonnaga (Schaufeli, Martinez, Pinto, Salanova, \& Bakker, 2002), on hilisemad uuringud näidanud, et läbipõlemist iseloomustavad dimensioonid ilmnevad ka koolikeskkonnas ning läbipõlemist on seega asutud uurima kooliõpilaste hulgas (Salmela-Aro, Kiuru, Leskinen, \& Nurmi, 2009; Salmela-Aro, Savolainen et al., 2009; Schaufeli et al., 2002). 
Akadeemilises kontekstis on läbipõlemist defineeritud kui kolmedimensioonilist afektiivset reaktsiooni kooliga seotud stressile, mida iseloomustavad õppetöö ülekoormusest tulenev kurnatus, õppetöö vastu tuntav küünilisus ning õppija vähenenud kompetentsus- ja tõhusustunne (Salmela-Aro et al., 2008; Salmela-Aro, Kiuru et al., 2009; Salmela-Aro, Savolainen et al., 2009; Schaufeli et al., 2002). Kurnatus iseloomustab läbipõlemise kontekstis individuaalse stressi dimensiooni (Maslach, 2003) ning selle all mõistetakse kooliga seotud pingeid, eelkõige liigsest koolitöö koormusest tulenevat kroonilist väsimust (Salmela-Aro, Kiuru et al., 2009) ning emotsionaalsete ja füüsiliste ressursside ammendumist (Maslach, 2003). Küünilisust on inimestega töötavate ametite korral algupäraselt käsitletud kui läbipõlemise isikutevahelist dimensiooni, mis areneb tavaliselt vastusena emotsionaalsele kurnatusele ja väljendub esmaselt enesekaitse reaktsioonina (Maslach, 2003). Koolikontekstis väljendub küünilisus $^{2}$ ükskõiksuses ja huvi kadumises koolitöö vastu ning kahtlustes selle tähenduslikkuse suhtes (Salmela-Aro, Kiuru et al., 2009). Ebaadekvaatsus iseloomustab läbipõlemise kontekstis enesehinnangulist dimensiooni (Maslach, 2003) ning viitab vähenenud kompetentsus- ja saavutustundele, aga ka ebaedukusele koolitöös (Salmela-Aro, Kiuru et al., 2009).

Nii kurnatus, ükskõiksus kui ka ebaadekvaatsustunne on emotsionaalse eraldumise ja kooliga mitteseotuse tunde kriitilised indikaatorid (SalmelaAro, Kiuru et al., 2009). Akadeemilise läbipõlemise ${ }^{3}$ märkideks on peetud ka heaolutunde puudumist (Vasalampi, Salmela-Aro, \& Nurmi, 2009), negatiivseid tundeid kooli suhtes ja õppimise mitteväärtustamist (Salmela-Aro, Read, Minkkinen, Kinnunen, \& Rimpela, 2018). Läbipõlemist on peetud eelkõige individuaalseks nähtuseks. Ainult väikese osa läbipõlemise avaldumise koguvariatiivsusest võib omistada kooli tasandile (Salmela-Aro et al., 2008). Oluline on ka eristada läbipõlemist muudest psühholoogilise heaoluga tihedalt seotud teguritest ning rõhutada, et akadeemiline läbipõlemine on kontekstispetsiifiline konstrukt, mida mõõdetakse õppimise kontekstis (Salmela-Aro, Kiuru et al., 2009).

Eestis on akadeemilist läbipõlemist põhikooli kontekstis vähe uuritud. Nende väheste uuringute hulka kuulub 2016. aastal korraldatud põhikooli matemaatika lõpueksami taustauuring (Kikas, Jõgi, Palu, Mädamürk, \& Luptova, 2016). Vaja oleks aga täpsemalt analüüsida läbipõlemise hindamiseks kasutatavate vahendite usaldusväärsust ja mõõtekindlust, kuna pole alust eeldada, et nii hinnatavad nähtused kui ka nende hindamiseks kasutatavad

2 Siinses artiklis kasutame edaspidi akadeemilise läbipõlemise küünilisuse (cynicism) alaskaalale viitava termini küünilisus asemel terminit ükskõiksus koolitöö suhtes, lühidalt ükskõiksus, mis vastab paremini alaskaala väidete sisule.

3 Edaspidi lühidalt läbipõlemine. 
mõõtevahendid on kultuuriliselt universaalsed (Marsella \& Yamada, 2010). Nimelt on leitud, et subjektiivse rahulolu tase võib peegeldada nii etnilisi kui ka ajaloolis-poliitilisi tegureid (Inglehart \& Klingemann, 2000) ning olla seotud kognitiivse arengu ja ressurssidega (Ots, 2014). Eelnevat arvesse võttes võiks küsida, kas toimetulekut toetavad oskused-omadused või nende seosed võivad eri keeletausta ja võimekusega õpilastel erineda.

\section{Üldvõimekus ja akadeemiline edukus}

On teada, et kindlat tüüpi vaimset pingutust nõudvates tegevustes edukamad inimesed on üldjuhul edukamad ka ülejäänud tegevustes, mis viitab, et mis tahes tüüpi vaimset pingutust nõudva tegevuse efektiivsus põhineb üldisel võimel, mida nimetatakse üldvõimekuseks (Mõttus, 2010). Üldvõimekust on defineeritud kui ,vaimset võimekust, mis muude asjade kõrval eeldab võimet arutleda, planeerida, lahendada ülesandeid, mõelda abstraktselt, saada aru keerulistest ideedest, õppida kiiresti ja õppida kogemustest" (Mõttus, Allik, \& Realo, 2011, lk 35). Üldvõimekus on üks akadeemilise edukuse olulisimaid ennustajaid (Rohde \& Thompson, 2007; Taub, Keith, Floyd, \& McGrew, 2008), sest see kirjeldab akadeemilise edu koguvariatiivsusest enam kui teised muutujad (Taub et al., 2008). Näiteks on seda peetud paremaks kooli- ja karjääriedukuse ennustajaks kui vanemate sotsiaal-majanduslikku staatust või hindeid (Strenze, 2007).

Siinses uurimuses oleme akadeemilist edukust käsitlenud matemaatikaoskuste kontekstis. Matemaatikaoskused on teiste reaalainete omandamise oluline alus ja seega prioriteet, kuid samas oma abstraktsuse tõttu sageli ärevuse allikas, seda ka võimekamate õpilaste puhul (Carey, Hill, Devine, \& Szücs, 2017).

Läbipõlemise ja üldvõimekuse seoseid on vähe uuritud, kuid senised uurimistulemused näitavad siiski, et läbipõlemine on seotud kehvema akadeemilise edukusega (May, Bauer, \& Fincham, 2015; Salmela-Aro et al., 2008, 2018; Tuominen-Soini \& Salmela-Aro, 2014) ning vähenenud tähelepanu ja probleemilahendusoskustega (May et al., 2015). Ka Eestis korraldatud põhikooli matemaatika lõpueksami taustauuringu (Kikas, Jõgi et al., 2016) tulemused kinnitasid, et eelkõige halvemaid tulemusi saavutanud õpilaste hulgas on teistest enam enese hinnangul ükskõikseid õpilasi. Samas leidus ka parima matemaatikatulemuse saanute hulgas 9\% õpilasi, kes hindasid end pigem ükskõikseks (ibid.). Sama kinnitavad Soomes tehtud uuringud: ka edukad õpilased võivad olla altid läbipõlemisele, kui nad kogevad tugevat stressi ja nende depressiivsete sümptomite tase on kõrge (Salmela-Aro et al., 2018; TuominenSoini \& Salmela-Aro, 2014). 


\section{Arenguuskumused}

Õpilastel on intelligentsuse olemuse kohta erinevaid arusaamu või „teooriaid“ (Dweck \& Leggett, 1988). Jäävususkumustega õpilased usuvad, et igal inimesel on kindel hulk kaasasündinud intelligentsust, mida ei saa muuta (nn jäävusteooria, entity theory), ning seetõttu võivad nad raskete ülesannete korral kahelda oma võimekuses, võtta vähem riske, loobuda pingutamisest ja saavutada vähem (Blackwell et al., 2007; Haimovitz \& Dweck, 2016). Vastupidi jäävususkumustega õpilastele peavad juurdekasvuuskumustega õpilased võimekust muudetavaks, millekski, mida saab raske töö, püsivuse, heade strateegiate kasutamise ja juhendamisega arendada (nn juurdekasvuteooria, incremental theory). Selle tulemusena kasutavad nad raskete ülesannete korral tõenäolisemalt meisterlikkusele orienteeritud strateegiaid ja suurendavad oma pingutusi, mistõttu nad õpivad või saavutavad rohkem (Blackwell et al., 2007; Haimovitz \& Dweck, 2016).

Uuringud on näidanud, et sama üldvõimekuse taseme korral kujundavad just arenguuskumused seda, kuidas õpilased reageerivad pingutust nõudvatele akadeemilistele ülesannetele. Kui jäävususkumustega õpilased on orienteeritud võimekuse hindamisele ja demonstreerimisele ning negatiivsena näiva tagajärje korral pigem loobuvad edasisest pingutusest, siis juurdekasvuuskumustega õpilased on ka ebaedu korral orienteeritud óppimisele ja pingutamisele ning valivad suurema tõenäosusega pingutust nõudvaid, teadmiste ja oskuste suurendamist võimaldavaid ülesandeid. (Blackwell et al., 2007; Dweck \& Leggett, 1988) Sellega seoses on leitud, et jäävususkumustega õpilastel on suurem kooliga seotud stressitase ja nõrgem tervis (Yeager et al., 2014) ning et juurdekasvuuskumustega õpilasi iseloomustab suurem psühholoogiline heaolu ja kaasatus (Zeng, Peng, \& Hou, 2016).

Varasematest uurimustest (nt Dweck, Chiu, \& Hong, 1995) on ilmnenud, et jäävus- ja juurdekasvuuskumusi ei saa vaadelda teineteise vastandina, vaid neid on soovitatav käsitleda eri tunnustena. Samal inimesel võib avalduda nii jäävus- kui ka juurdekasvuuskumustele viitavaid tõlgendusi, kuid juurdekasvuuskumuste hindamist mõjutab sotsiaalne soovitavus ning jäävususkumuste hindamine võimaldab inimesi paremini eristada (ibid.).

\section{Akadeemiline psühholoogiline säilenõtkus}

Psühholoogilist säilenõtkust on defineeritud kui võimet edukalt kohaneda ja areneda märkimisväärselt raskes, riskirohkes keskkonnas (HKS, 2014) ning seda on vaadeldud kui edukat kohanemisprotsessi, -võimekust või -väljundit pingutust nõudvates olukordades (Masten, Best, \& Garmezy, 1990). 
Akadeemiline psühholoogiline säilenõtkus ${ }^{4}$ on tihedalt seotud isikliku säilenõtkusega, mis iseloomustab võimet tulla toime pingutust nõudvates ja rasketes olukordades, kuid mis ilmneb peamiselt hariduskontekstis (Cassidy, 2016).

Kuigi säilenõtkust on uuritud eelkõige vähemusrahvuste ja madala sooritustasemega õpilaste hulgas (nt Borman \& Overman, 2004), on selle uurimine asjakohane kõigi õpilaste puhul, kuna mingil hetkel võivad kõik õpilased sattuda ebasoodsasse olukorda, seista kooliga seotud raskuste ees või tunda koolipinget (Martin \& Marsh, 2006; Yeager \& Dweck, 2012). Säilenõtkust parandavateks teguriteks on peetud enesetõhusust, püsivust (Martin \& Marsh, 2006), töökust (Johnsen, Ortiz-Barreda, Rekkedal, \& Iversen, 2017), kontrollitunnet, planeerimisoskust, madalat ärevustaset (Martin \& Marsh, 2006), positiivset suhtumist kooli ja suurt haridusega seotud ambitsiooni (Johnsen et al., 2017). Säilenõtkus omakorda ennustab koolimeeldivust, tunnitegevustesse kaasatust ja üldist enesehinnangut (Martin \& Marsh, 2006).

Uurimistulemused on näidanud, et säilenõtkuse ja läbipõlemise (GarciaIzquierdo, Rios-Risquez, Carrillo-Garcia, \& de los Angeles Sabuco-Tebar, 2018; Guo et al., 2018), emotsionaalse kurnatuse, enesetõhususe ja psühholoogilise heaolu vahel on tugev seos (Garcia-Izquierdo et al., 2018). Säilenõtkuse tähtsust on rõhutatud stressi ja läbipõlemise vähendamisel (Richards, LevesqueBristol, Templin, \& Graber, 2016) ning on leitud, et emotsionaalselt kurnavates olukordades on säilenõtkusel psühholoogilise heaolu ennustajana oluline vahendav roll (Garcia-Izquierdo et al., 2018).

\section{Uurimuse kontekst}

Tänapäeva Eesti on mitmerahvuseline ühiskond, kus eestlaste (69\%) kõrval moodustab teise suurema rahvusrühma venelastest koosnev rahvusvähemus (25\%) (Eesti Statistikaamet, 2018). Eesti haridussüsteemi on rahvusvaheliselt peetud unikaalseks (Soll, Salvet, \& Masso, 2015), kuna vähemusrühm on saanud valida õppekeeleks eri keeli ning Eesti põhikooli riiklikku õppekava (2018) järgivates munitsipaal- ja riigikoolides toimub õpe põhikooliastmes kas eesti või vene keeles.

Eesti on põhihariduse tulemuslikkuse ja võrdsuse tagamise poolest Euroopas tippriik ning maailmas tippu kuuluvate riikide hulgas (PISA, 2018). Kuigi erinevusi eesti ja vene keelt kõnelevate õpilaste kooliedukuse vahel on käsitletud mitmes uuringus (nt PISA, TIMSS), väärivad eraldi uurimist enamus- ja vähemusrahvuse vahelised varjatumad sotsiaal-kognitiivsed erinevused, mis võivad samuti seostuda kooliedukusega. Nii näiteks on vähem tähelepanu

$4 \quad$ Edaspidi lühidalt säilenõtkus. 
pööratud eesti ja vene õppekeelega õpilaste emotsionaalse heaolu ja toimetuleku erinevustele, samuti on olemasolevad andmed pigem vastuolulised. Näiteks ei erine PISA 2015 andmetel eesti ja vene õppekeelega koolides õpilaste üldine eluga rahulolu (PISA, 2018), kuid Eesti üldhariduskoolide 5., 7. ja 9. klassi õpilaste hulgas tehtud tervisekäitumisuuringu põhjal on leitud, et mitte-eesti kodukeelega õpilased peavad kooliskäimist ebameeldivaks ning koolitööd pingelisemaks kui eesti kodukeelega õpilased (vastavalt 45\% ja 36\% ning $47 \%$ ja $40 \%$, kuid aruandes puudub info erinevuste statistilise olulisuse kohta) (Aasvee et al., 2016). Põhikooli matemaatika lõpueksami taustauuringu tulemustest nähtub, et õppetöö suhtes on ükskõiksemad pigem eesti õppekeelega õpilased, kes on õppimisega vähem rahul ning tunnetavad enam ülekoormatust (Kikas, Jõgi et al., 2016). Kirjeldatu viitab edasise uurimise vajadusele ning seetõttu keskendume praeguses uurimuses eesti ja vene õppekeelega õpilaste läbipõlemise erinevuste kindlakstegemisele ja läbipõlemisega potentsiaalselt seostuvate tegurite analüüsimisele, võttes aluseks eri õppekeelega rühmad.

\section{Eesmärk ja uurimisküsimused}

Artiklis võtame vaatluse alla eesti ja vene õppekeelega koolides avalduva akadeemilise läbipõlemise, mis on õpilaste toimetuleku ja heaoluga seotud oluline tegur (vt Salmela-Aro, Savolainen et al., 2009; Schaufeli et al., 2002). Spetsiifilisem eesmärk on analüüsida eesti ja vene õppekeelega 8 . klassi õpilaste akadeemilise läbipõlemise erinevusi ja läbipõlemise seoseid eri kognitiivsete (matemaatikaoskused ja üldvõimekus) ning sotsiaal-kognitiivsete teguritega (arenguuskumused ja akadeemiline psühholoogiline säilenõtkus). Kuna meile teadaolevalt on Eestis läbipõlemist, arenguuskumusi ja säilenõtkust õppekeelte kontekstis vähe uuritud, annavad praeguse uuringu tulemused aluse edasisteks uuringuteks ja uurimisvahendite täiendamiseks, arvestades õppekeelte erinevusi.

Uuringu tarbeks sõnastasime järgmised uurimisküsimused.

1. Kas ja mil määral erinevad eesti ja vene õppekeelega 8 . klassi õpilased enesekohaste hinnangute põhjal oma läbipõlemise tasemes?

2. Millised kognitiivsed ja sotsiaal-kognitiivsed tegurid ennustavad läbipõlemist ning kas need tegurid on eri õppekeelega rühmades erinevad?

3. Kuidas on eri õppekeele ja võimekusega õpilaste rühmades läbipõlemine seotud arenguuskumuste ja säilenõtkusega? 


\section{Metoodika}

\section{Valim}

Uuringu valimisse kuulusid projektis „Õpetajate toetamine üldpädevuste arendamisel ${ }^{\text {‘5 }}$ osalenud 12 Tallinna üldhariduskooli 8. klassi õpilased. Koolide valik oli juhuslik ning uuringus osalenud koolide seas oli viis vene ja seitse eesti õppekeelega kooli. Uuringus osales kokku 655 õpilast, kuid siinse artikli valimi moodustasid vaid need õpilased, kelle kodu- ja õppekeel kattusid. Peale selle kriteeriumi arvestamist ja täitmata küsimustike mahaarvamist moodustas uuringu lõpliku valimi 429 õpilast, kellest 255 (59,4\%) õppisid eesti ja 174 (40,6\%) vene õppekeelega koolis. Valimisse kuulunud õpilaste hulgas oli 223 poissi (52\%) ja 206 tüdrukut (48\%). Uuringus osalenud ópilaste keskmine vanus oli $14,02(S D=0,38)$ aastat.

\section{Andmekogumine}

Uurimistöö andmed on kogutud projekti „Õpetajate toetamine üldpädevuste arendamisel“ raames. 2015. aasta sügisel saadeti koolide juhtkondadele kirjad, kus kirjeldati projekti. Koolid, kes nõustusid projektis osalema, said projekti tutvustavad kirjad ja informeeritud nõusoleku lehed, mis tuli edastada lapsevanematele. Uuringust võtsid osa vaid need õpilased, kelle vanemad ei keeldunud lapse osalemisest. Andmeid koguti 2015. aasta sügisel. Õpilasi teavitati, et küsimustikule vastamine on vabatahtlik ja andmed on konfidentsiaalsed.

Uuritud konstruktide hindamiseks kasutatud mõõtevahendid moodustasid osa projektis kasutatud testipaketist ning olid esitatud vastavalt kas testide või enesekohaste küsimustikena muude mõõtevahendite hulgas. Kogu mõõtevahendite komplekti täitmisele kulus õpilastel üks koolitund. Teste ja küsimustikke täideti kooli arvutiklassis uurimisrühma teadurite või assistentide juhendamisel, ülesannete ja küsimuste esitamise järjekord oli kõigi laste puhul sama. Eesti ja vene õppekeelega koolides kasutatud ülesanded ja enesekohased skaalad olid kahes õppekeeles ning identsed.

\section{Mõõtevahendid}

Õpilaste läbipõlemist, jäävususkumusi ja säilenõtkust hindasime enesekohaste küsimustikega. Õpilaste kognitiivse soorituse väljaselgitamiseks kasutasime

Artikli aluseks olev uuring on jätkuprojekt Haridus- ja Teadusministeeriumi rahastatud projektile „Üldpädevused ja nende hindamine 2011-2014“, täpsemalt „Õpetajate toetamine üldpädevuste arendamisel“ (vt Kikas, Aus et al., 2016). 
matemaatikaoskuste testi ning üldvõimekuse hindamiseks Raveni progresseeruvate maatriksite testi D- ja E-osa.

Läbipõlemist mõõtsime seitsmeväitelise ühefaktorilise skaalaga, mis oli originaalvariandis kolmefaktoriline üheksaväiteline skaala (vt Salmela-Aro, Kiuru et al., 2009, eesti keelde adapteerinud Okas, 2014). Väidete hulka kuulub näiteks järgmine väide: „Tunnen, et olen koolitöödega üle koormatud“. Õpilased andsid väidetele hinnangu kuuepunktisel skaalal $(1=$ pole üldse nõus; 6 = täitsa nõus). Analüüsides kasutasime läbipõlemise muutuja skoorina kõigi mõõdetud väidete keskmist skoori - suurem skoor näitab kõrgemat enesehinnatud läbipõlemise määra. Läbipõlemise lõpliku seitsmeväitelise skaala sisereliaablus oli hea (Cronbachi $\alpha=0,85$ eesti óppekeele puhul ja 0,78 vene õppekeele puhul).

Matemaatikaoskusi mõõtsime Anu Palu koostatud viieülesandelise matemaatikaoskuste testiga, mis vastab põhikooli riiklikule õppekavale (2018). Iga õige vastuse korral sai õpilane ühe punkti. Analüüsides kasutasime õigete vastuste summat.

Üldvõimekust, mis hõlmab õpilaste mitteverbaalset järeldamisoskust, täidesaatvaid funktsioone, planeerimisoskust ja visuaalsete analoogiate leidmist, mõõtsime Raveni (1981) progresseeruvate maatriksite testi abil. Kasutasime vanuserühmale vastavat D- ja E-osa. Test koosneb 24-st arvutile kohandatud maatriksülesandest. Õige vastuse korral sai õpilane ühe punkti. Analüüsides kasutasime D- ja E-osa testi õigete vastuste summat.

Jäävususkumusi mõõtsime kuueväitelise skaalaga, mis oli algsel kujul kaheksaväiteline (vt Dweck et al., 1995; Schommer-Aikins, Mau, Hutter, \& Brookhart, 2000). Skaala hõlmab näiteks väidet „Võimekus on omadus, mida ei saa koolis õppimisega eriti muuta“. Õpilased hindasid väiteid viiepunktisel skaalal $(1=$ pole üldse nõus; 5 = olen täiesti nõus). Analüüsides kasutasime jäävususkumuste muutuja skoorina mõõdetud väidete keskmist skoori - suurem skoor näitab kalduvust jäävususkumuste poole. Eestikeelsel versioonil oli lõpliku kuueväitelise skaala sisereliaablus (Cronbachi $\alpha$ ) 0,65, venekeelsel versioonil 0,77 .

Säilenõtkust mõõtsime uuringu jaoks kohandatud viieväitelise skaalaga (Martin \& Marsh, 2006), kuhu kuulus muu hulgas järgmine väide: „Tulen tagasilöökidega (nt halbade hinnete või koolitööd puudutava kriitikaga) hästi toime“. Õpilased hindasid väiteid kuuepunktisel skaalal ( 1 = pole üldse nõus; 6 = täitsa nõus). Analüüsides kasutasime säilenõtkuse muutuja skoorina mõõdetud väidete keskmist skoori - suurem skoor viitab kõrgemale säilenõtkuse tasemele. Lõpliku viieväitelise skaala sisereliaablus oli hea (Cronbachi $\alpha=0,86$ eesti óppekeele puhul ja 0,83 vene õppekeele puhul). 


\section{Andmeanalüïs}

Andmeid analüüsisime statistikapaketiga SPSS 25.0. Kinnitava faktoranalüüsi ja invariantsustestide tegemiseks kasutasime Ri struktuurvõrrandite modelleerimise paketti lavaan (Rosseel, 2012). Mudelite hindamisel kasutasime MLRestimeerimist (maximum likelihood estimation with non-normality robust standard errors), mis käsitleb puuduvaid väärtusi, arvestades andmete mittevastavust normaaljaotusele (Wang \& Wang, 2012). Mudelite sobivusindeksite hindamisel lähtusime van de Schooti, Lugtigi ja Hoxi (2012) pakutud mudelisobivuse kriteeriumitest. Kuna hii-ruut-testi tulemus sõltub valimi suurusest (van de Schoot et al., 2012), keskendusime mudeli sobivuse hindamisel eelkõige teistele mudelisobivusindeksitele: heaks hindasime mudeli, kui CFI (comparative fit index) väärtus oli vähemalt 0,95 ning RMSEA (root mean square error of approximation) ja SRMRi (standardized root mean square residual) väärtus alla 0,08. Mõõtmise invariantsusanalüüsi käigus hindasime konstruktide rühmadevaheliste võrdluste eelduseks olevat meetrilist (faktorkaalude) ja skalaarset (faktorkaalude ja vabaliikmete) invariantsust, mille kinnitamise tulemusena on analüüsitavaid rühmi võimalik skooride alusel võrrelda (van de Schoot et al., 2012). Invariantsuse hindamisel ja eri mudelite vorrdlemisel vaatasime samuti $C F I$ muutust $(\triangle \mathrm{CFI})$, mille väärtus 0,01 või alla 0,01 võrreldavate mudelite vahel viitab rühmade invariantsusele (Cheung \& Rensvold, 2002).

\section{Tulemused}

\section{Eelanalüïs: skaalade mõõtekindluse ja konstruktide võrreldavuse kontrollimine}

Enne põhianalüüside tegemist uurisime psühholoogiliste konstruktide faktorstruktuuri ning tegime meetrilise ja skalaarse invariantsuse testid. Nende tulemusena selgusid mõõtemudelite sobivusindeksid ning eesti ja vene õppekeelega õpilaste näitajate võrreldavus uuritavate konstruktide kontekstis.

\section{Läbipõlemine}

Uuringud on näidanud, et läbipõlemine on terviklik konstrukt, mille aladimensioonid on omavahel tihedalt seotud (Salmela-Aro, Kiuru et al., 2009). Näiteks on Soome kesk- ja kutsekoolide õpilaste uuringus jäänud faktoritevahelised korrelatsioonikoefitsiendid vahemikku 0,58-0,89 (ibid.). Eesti üliõpilastel on ulatunud faktoritevahelised korrelatsioonid ka üle 0,90 (Okas, 2014). Praeguses uuringus hindasime erinevaid läbipõlemise mõõtmise mudeleid ja võrdlesime nii ühe- kui ka kolmefaktorilise mudeli vastavust andmetele. 
Mudelite võrdlemise tulemusena otsustasime jätkata analüüsi ühefaktorilise mudeliga, kus lubasime kahe väitepaari jääkliikmetel korreleeruda. Samuti otsustasime edasisest analüüsist välja jätta kaks väidet, kuna nende puhul ei olnud rühmade võrdlemise eeldusnõue täidetud. Mõõtmise invariantsusanalüüsi käigus analüüsisime esmalt meetrilist ja seejärel skalaarset invariantsust ning lõplik seitsmeväiteline mudel oli skalaarse invariantsuse osas aktsepteeritav (skalaarne $v s$. algmudel: $\Delta \chi^{2}=15,73 ; \Delta d f=6 ; p=0,02 ; \Delta \mathrm{CFI}=0,01$ ).

Võrreldes ühe- ja kolmefaktorilist mudelit, selgus, et kolmefaktorilise mudeli sobivusindeksid $\left(\chi^{2}=28,22 ; d f=20 ; p=0,104\right.$; CFI $=0,99$; RMSEA $=$ $0,044$; SRMR $=0,031)$ olid paremad kui ühefaktorilise mudeli omad $\left(\chi^{2}=\right.$ 45,$45 ; d f=24 ; p=0,005$; CFI $=0,97$; RMSEA $=0,065$; SRMR =0,036). Siiski olid kolmefaktorilise mudeli latentsete tunnuste korrelatsioonid tugevad ning ühel juhul isegi üle 1 (standardiseeritud korrelatsioonikoefitsiendid vahemikus 0,55-1,09). Üle 1 ulatuvad korrelatsioonid viitavad latentsete tunnuste vahelisele multikollineaarsusele, põhjustades probleeme mudeli hindamisel (Lei \& $\mathrm{Wu}, 2007)$. Seega ei saa meie valimi puhul kirjeldada läbipõlemist erinevate latentsete faktoritega. Seetõttu otsustasime läbipõlemist edasistes analüüsides käsitleda ühefaktorilise konstruktina. Ühefaktoriline mudel sobis nii eesti keeles $\left(\chi^{2}=25,35 ; d f=12 ; p=0,013\right.$; CFI $=0,97$; RMSEA $=0,066$; SRMR $=$ $0,034$; faktorkaalud vahemikus $0,599-0,742)$ kui ka vene keeles $(\chi 2=19,90$; $d f=12 ; p=0,069 ; \mathrm{CFI}=0,96$; RMSEA $=0,063$; SRMR $=0,039$; faktorkaalud vahemikus $0,339-0,725$ ) vastanud õpilaste andmetega.

\section{Jäävususkumused}

Uurisime kaheksaväitelise jäävususkumuste mudeli vastavust andmetele. Esmalt otsustasime edasisest analüüsist välja jätta väite „Intelligentsus on omadus, mida ei saa koolis õppimisega eriti muuta“ ja kasutada paralleelväidet „Võimekus on omadus, mida ei saa koolis õppimisega eriti muuta“. Rühmade meetrilise ja skalaarse invariantsuse hindamise tulemusena jätsime edasisest analüüsist välja veel ühe väite, kuna eesti ja vene õppekeelega rühmad ei olnud selle väite alusel võrreldavad. Invariantsusanalüüsi tulemusena saadud lõplik mudel oli skalaarse invariantsuse osas aktsepteeritav (skalaarne vs. algmudel: $\Delta \chi^{2}=10,74 ; \Delta d f=5 ; p=0,06 ; \Delta C F I=0,01$ ). Lõplik mudel sobis nii eesti keeles $\left(\chi^{2}=12,69 ; d f=9 ; p=0,177\right.$; CFI = 0,97; RMSEA = 0,040; $\operatorname{SRMR}=0,035$; faktorkaalud vahemikus $0,409-0,549)$ kui ka vene keeles $\left(\chi^{2}=12,06 ; d f=9\right.$; $p=0,210 ; \mathrm{CFI}=0,98$; RMSEA $=0,044 ;$ SRMR $=0,040$; faktorkaalud vahemikus $0,516-0,634)$ vastanud õpilaste andmetega. 


\section{Säilenõtkus}

Kontrollisime seitsmeväitelise säilenõtkuse mudeli vastavust andmetele (kahe väitepaari jääkliikmetel lubasime korreleeruda). Samuti otsustasime edasisest analüüsist välja jätta kaks väidet, kuna nende korral ei olnud rühmade edasise võrdlemise eeldusnõuded täidetud. Mõõtmise invariantsusanalüüsi käigus analüüsisime meetrilist ja skalaarset invariantsust ning lõplik mudel oli skalaarse invariantsuse osas aktsepteeritav (skalaarne $v s$. algmudel: $\Delta \chi^{2}=6,97 ; \Delta d f=4 ; p$ $=0,14 ; \Delta \mathrm{CFI}=0,00)$ nii eesti õppekeele puhul $\left(\chi^{2}=10,05 ; d f=3 ; p=0,018\right.$; CFI $=0,98 ;$ RMSEA $=0,096 ;$ SRMR $=0,020$; faktorkaalud vahemikus 0,574-0,798) kui ka vene õppekeele puhul $\left(\chi^{2}=8,70 ; d f=3 ; p=0,034\right.$; $\mathrm{CFI}=0,97$; RMSEA $=$ 0,108 ; SRMR $=0,023$; faktorkaalud vahemikus $0,527-0,793$ ).

\section{Hinnatud konstruktide kirjeldavad statistikud õppekeelte kaupa}

Eesti ja vene õppekeelega õpilaste läbipõlemise näitajate erinevusi analüüsisime esmalt kirjeldava statistika meetodite abil. Erinevuste peamõju õppekeelte kaupa uurisime ühefaktorilise dispersioonanalüüsiga. Tabelis 1 on toodud analüüsitud näitajate kirjeldavad statistikud, tunnustevahelised korrelatsioonid ja rühmade erinevused õppekeelte kaupa.

Tabel 1. Hinnatud tunnuste kirjeldavad statistikud, tunnustevahelised korrelatsioonid ja rühmadevahelised erinevused õppekeelte kaupa

\begin{tabular}{llllllllll}
\hline $\begin{array}{l}\text { Mõõdetav } \\
\text { konstrukt }\end{array}$ & & $M$ & $S D$ & Min & Max & 1 & 2 & 3 & 4 \\
\hline $\begin{array}{c}\text { 1. Läbi- } \\
\text { põlemine }\end{array}$ & Eesti $(N=253)$ & 3,33 & 1,05 & 1 & 6 & - & & \\
& Vene $(N=164)$ & 3,33 & 0,94 & 1 & 6 & - & & & \\
\hline $\begin{array}{c}\text { 2. Mate- } \\
\text { maatika- } \\
\text { oskused }\end{array}$ & Eesti $(N=255)$ & $\mathbf{3 , 1 9}$ & $\mathbf{1 , 3 6}$ & 0 & 5 & $-0,07$ & - & & \\
\hline $\begin{array}{c}\text { 3. Üld- } \\
\text { võimekus }(N=174)\end{array}$ & $\mathbf{2 , 7 8}$ & $\mathbf{1 , 4 5}$ & 0 & 5 & $-0,09$ & - & & \\
\hline $\begin{array}{c}\text { 4. Jäävus- } \\
\text { usku- } \\
\text { mused }\end{array}$ & Eesti $(N=254)$ & $\mathbf{1 1 , 9 6}$ & $\mathbf{4 , 5 8}$ & 1 & 21 & $-0,01$ & $0,32^{* *}$ & - & \\
\hline $\begin{array}{c}\text { 5. Säile- } \\
\text { nõtkus }\end{array}$ & Eene $(N=1725)$ & 2,45 & 0,67 & 1 & 5 & $0,27^{* *}$ & $-0,06$ & $-0,18^{* *}$ & - \\
\hline
\end{tabular}

Märkused. ${ }^{*}=p<0,05 ;{ }^{* *}=p<0,01$. Poolpaksus kirjas on esitatud statistiliselt olulised erinevused eesti ja vene õppekeelega õpilaste vahel. Min = vähim mõõdetud väärtus, max = suurim mõõdetud väärtus. 
Tabelist 1 nähtub, et eesti ja vene õppekeelega õpilaste läbipõlemise näitajad on samad ja õppekeeliti statistiliselt olulist erinevust ei ilmnenud $[F(1,413)=0,04$, $p>0,05$, osaline $\left.\eta^{2}=0,000\right]$.

Eesti õppekeelega õpilaste matemaatikaoskuste testi tulemused ja üldvõimekuse näitajad on paremad kui vene õppekeelega õpilaste vastavad näitajad (vt tabel 1). Õppekeele peamõju oli nii matemaatikaoskuste testi $[F(1,425)=$ $9,13, p<0,01$, osaline $\left.\eta^{2}=0,021\right]$ kui ka üldvõimekuse näitaja $[F(1,424)=4,41$, $p<0,05$, osaline $\eta^{2}=0,010$ ] puhul statistiliselt oluline. Nende näitajate osas saavutasid eesti õppekeelega õpilased paremaid tulemusi kui vene õppekeelega õpilased.

Eesti ja vene õppekeelega õpilaste jäävususkumustes õppekeeliti statistiliselt olulisi erinevusi ei ilmnenud [õppekeele peamõju: $F(1,421)=0,78, p>0,05$, osaline $\left.\eta^{2}=0,002\right]$, kuid see ilmnes säilenõtkusele antud hinnangutes $[F(1,413)$ $=9,62, p<0,01$, osaline $\left.\eta^{2}=0,023\right]$. Vene õppekeelega õpilased hindasid end säilenõtkemaks kui eesti õppekeelega eakaaslased.

\section{Hinnatud konstruktide seosed läbipõlemisega õppekeelte kaupa}

Eesti ja vene õppekeelega õpilaste läbipõlemise seoseid matemaatikaoskuste, üldvõimekuse, jäävususkumuste ja säilenõtkuse näitajatega ning nende tunnuste astmelist mõju läbipõlemise ennustamisel analüüsisime hierarhilise lineaarse regressioonanalüüsi meetodi abil. Tulemused on kokkuvõtvalt toodud tabelites 2 ja 3.

Eesti õppekeelega õpilaste valimil põhinev hierarhiline lineaarne regressioonanalüüs näitas, et esimesel sammul mudelis sisaldunud matemaatikaoskused ei ennustanud läbipõlemist olulisel määral $[F(1,250)=1,29, p>0,05]$, kirjeldades 1\% läbipõlemise variatiivsusest (vt tabel 2). Samuti ei parandanud mudelit üldvõimekuse lisandumine $[F(2,249)=0,66, p>0,05]$. Seega, kognitiivsed näitajad ei osutunud eesti õppekeelega õpilaste läbipõlemise ennustamisel oluliseks.

Mudeli täiendamine jäävususkumustega võimaldas kirjeldada lisaks 7\% läbipõlemise variatiivsusest ning mudeli kirjeldusmäära muutus oli statistiliselt oluline $[F(3,248)=7,08, p<0,01]$. Säilenõtkus lisas mudeli kirjeldusvõimele veel $24 \%$ läbipõlemise ilmnemise variatiivsusest ja ka sel korral oli mudeli kirjeldusmäära muutus statistiliselt oluline $[F(4,247)=28,27, p<0,01]$.

Seega ennustasid eesti õppekeelega õpilaste läbipõlemist eelkõige sotsiaalkognitiivsed tegurid (jäävususkumused ja säilenõtkus), kusjuures nende õpilaste kõige olulisem läbipõlemise ennustaja oli madal säilenõtkuse tase, mis üksinda kirjeldas läbipõlemise variatiivsusest $24 \%$. Lõplik mudel kirjeldas $31 \%$ eesti õppekeelega õpilaste läbipõlemise ilmnemise variatiivsusest. 
Tabel 2. Hierarhilise regressioonanalüüsi tulemused eesti õppekeelega õpilaste läbipõlemise ennustamisel

\begin{tabular}{lccccc}
\hline Tunnus & $\boldsymbol{\beta}$ & $\boldsymbol{t}$ & $\boldsymbol{s r ^ { 2 }}$ & $\boldsymbol{R}^{2}$ & $\boldsymbol{R}^{2}$ \\
\hline Samm 1 & & & & 0,01 & 0,01 \\
$\quad$ Matemaatikaoskused & $-0,07$ & $-1,14$ & 0,01 & & \\
\hline Samm 2 & & & & 0,01 & 0,00 \\
$\quad$ Matemaatikaoskused & $-0,08$ & $-1,13$ & 0,01 & & \\
Üldvõimekus & 0,01 & 0,17 & 0,01 & & \\
\hline Samm 3 & & & & 0,08 & 0,07 \\
Matemaatikaoskused & $-0,08$ & $-1,17$ & 0,01 & & \\
Üldvõimekus & 0,06 & 0,92 & 0,00 & & \\
$\quad$ Jäävususkumused & 0,28 & $4,45^{* *}$ & 0,07 & & \\
\hline Samm 4 & & & & 0,31 & 0,24 \\
Matemaatikaoskused & $-0,07$ & $-1,33$ & 0,00 & & \\
Üldvõimekus & 0,07 & 1,19 & 0,00 & & \\
Jäävususkumused & 0,21 & $3,94^{* *}$ & 0,04 & & \\
Säilenõtkus & $-0,49$ & $-9,20^{* *}$ & 0,24 & & \\
\hline
\end{tabular}

Märkus. ${ }^{*}=p<0,05 ;{ }^{*}=p<0,01$.

Tabel 3. Hierarhilise regressioonanalüüsi tulemused vene õppekeelega õpilaste läbipõlemise ennustamisel

\begin{tabular}{lccccc}
\hline Tunnus & $\boldsymbol{\beta}$ & $\boldsymbol{t}$ & $\boldsymbol{s r ^ { 2 }}$ & $\boldsymbol{R}^{2}$ & $\boldsymbol{\Delta} \boldsymbol{R}^{2}$ \\
\hline Samm 1 & & & & 0,01 & 0,01 \\
$\quad$ Matemaatikaoskused & $-0,09$ & $-1,10$ & 0,01 & & \\
\hline Samm 2 & & & & 0,02 & 0,02 \\
$\quad$ Matemaatikaoskused & $-0,05$ & $-0,59$ & 0,00 & & \\
$\quad$ Üldvõimekus & $-0,13$ & $-1,60$ & 0,02 & & \\
\hline Samm 3 & & & & 0,14 & 0,12 \\
$\quad$ Matemaatikaoskused & $-0,04$ & $-0,48$ & 0,00 & & \\
$\quad$ Üldvõimekus & $-0,09$ & $-1,21$ & 0,01 & & \\
$\quad$ Jäävususkumused & 0,34 & $4,61^{* *}$ & 0,11 & & \\
\hline Samm 4 & & & & 0,22 & 0,08 \\
$\quad$ Matemaatikaoskused & $-0,07$ & $-0,90$ & 0,00 & & \\
Üldvõimekus & $-0,12$ & $-1,58$ & 0,01 & & \\
$\quad$ Jäävususkumused & 0,37 & $5,17^{* *}$ & 0,13 & & \\
Säilenõtkus & $-0,29$ & $-4,10^{* *}$ & 0,08 & & \\
\hline
\end{tabular}

Märkus. ${ }^{*}=p<0,05 ;{ }^{* *}=p<0,01$. 
Vene õppekeelega õpilaste valimil põhinev hierarhiline lineaarne regressioonanalüüs näitas samuti, et esimesel sammul mudelis sisaldunud matemaatikaoskused ei ennustanud läbipõlemist olulisel määral $[F(1,162)=1,20$, $p>0,05]$, kirjeldades $1 \%$ läbipõlemise variatiivsusest (vt tabel 3). Samuti ei parandanud mudelit üldvõimekuse lisandumine $[F(2,161)=1,88, p>0,05]$, mille tulemusena suurenes mudeli kirjeldusvõime vaid $1 \%$.

Jäävususkumuste lisamine mudelisse võimaldas kirjeldada lisaks 12\% läbipõlemise variatiivsusest ja mudeli kirjeldusmäära muutus oli statistiliselt oluline $[F(3,160)=8,50, p<0,01]$. Viimase sammuna lisatud säilenõtkus suurendas veelgi mudeli kirjeldusvõimet, lisades juurde $8 \%$ läbipõlemise ilmnemise variatiivsusest, ja ka see muutus oli statistiliselt oluline $[F(4,159)=11,21$, $p<0,01]$.

Eeltoodust ilmneb sama tendents mis eesti õppekeelega õpilastel: nimetatud tunnuste lisamisel (vt tabel 3) vene õppekeelega õpilaste läbipõlemist ennustavasse regressioonmudelisse ei olnud kognitiivsed tegurid (matemaatikaoskused ja üldvõimekus) läbipõlemise olulised ennustajad. Ka vene õppekeelega õpilaste läbipõlemist ennustavad eelkõige sotsiaal-kognitiivsed tegurid (jäävususkumused ja säilenõtkus), kusjuures nende kõige olulisem läbipõlemise ennustaja on kalduvus jäävususkumustele, mis üksinda kirjeldas läbipõlemise variatiivsusest $13 \%$. Lõplik mudel kirjeldas $22 \%$ vene õppekeelega õpilaste läbipõlemise ilmnemise variatiivsusest.

Kokkuvõttes ennustasid läbipõlemist mõlemas rühmas statistiliselt olulisel määral just sotsiaal-kognitiivsed tegurid: jäävususkumused ja madalam säilenõtkuse tase. Kui eesti koolide õpilastel osutus olulisemaks läbipõlemise ennustajaks säilenõtkus, siis vene koolide õpilastel jäävususkumused. Jäävususkumuste ja säilenõtkuse seoseid läbipõlemisega on õppekeelte kaupa (koosmõjuanalüüsi tulemustena) visualiseeritud joonistel 1 ja 2.

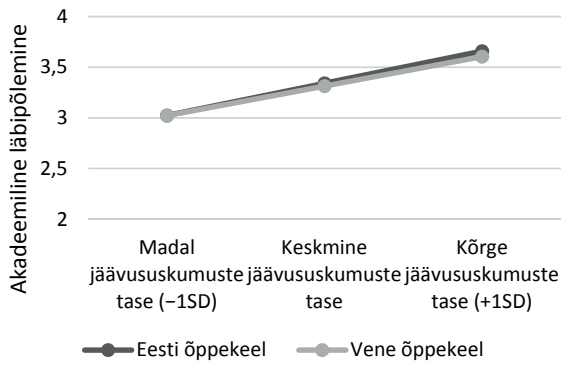

Joonis 1. Jäävususkumused ja õppekeel läbipõlemise ennustajana, $F(1,412)=0,08, p=0,781$

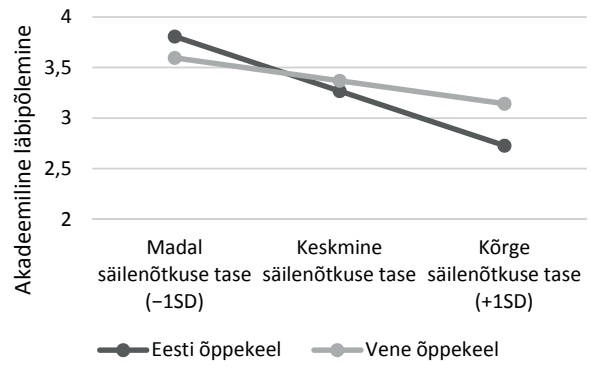

Joonis 2. Säilenõtkus ja õppekeel läbipõlemise ennustajana, $F(1,413)=11,25$, $p=0,001$ 


\section{Läbipõlemise ja sotsiaal-kognitiivsete tegurite seosed erineva võimekusega õpilaste rühmades eri õppekeelte puhul}

Läbipõlemise ning säilenõtkuse ja jäävususkumuste seoseid uurides ei ilmnenud üldvõimekuse alusel moodustatud võimekusrühmade puhul olulist koosmõju. Samuti ei ilmnenud, et jäävususkumused oleksid eri võimekusega õpilaste rühmades läbipõlemisega erinevalt seotud, seda ei eesti ega ka vene õppekeelega õpilaste puhul.

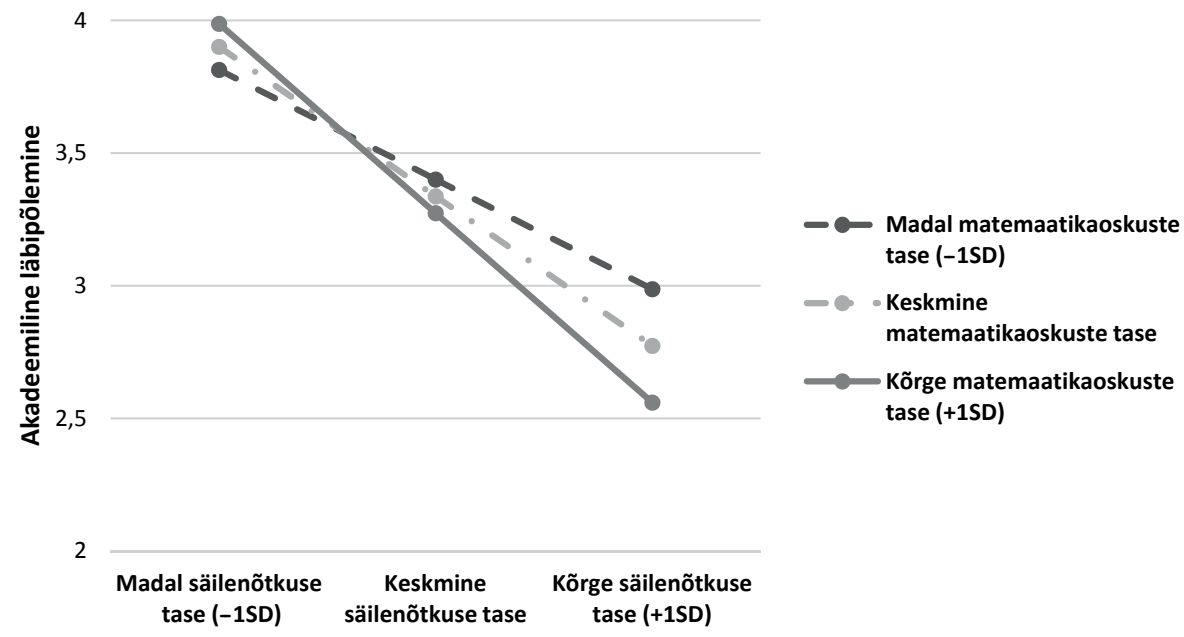

Joonis 3. Psühholoogiline säilenõtkus ja matemaatikaoskused eesti õppekeelega õpilaste läbipõlemise ennustajana

Matemaatikaoskuste põhjal moodustatud eri võimekusega õpilaste rühmi analüüsides ilmnes läbipõlemise ennustamisel säilenõtkuse koosmõju vaid eesti õppekeelega õpilaste puhul $[F(1,249)=6,15, p=0,014]$. Kõige tugevam seos läbipõlemise ja säilenõtkuse vahel avaldus eesti õpilaste hulgas just paremate matemaatikaoskustega õpilaste puhul, teisisõnu, säilenõtkuse madala taseme korral on läbipõlemisele altimad pigem paremate matemaatikaoskustega õpilased, kelle õppekeel on eesti keel (vt joonis 3).

\section{Arutelu}

Läbipõlemist teismeeas tuleks võtta tõsiselt, kuna see ei vii mitte ainult hilisemate depressiivsete sümptomite kogemiseni (Salmela-Aro, Savolainen et al., 2009), vaid subjektiivse heaolu vähenemine suhestub ka üldvõimekuse teguritega (Liston, McEwen, Casey, \& Posner, 2009) ning akadeemilisse ellu 
kaasatusega. Näiteks näitas Soome 16-18-aastaste noorukite seas tehtud uuring, et tugevate ükskõiksusilmingutega noortel on neli korda suurem tõenäosus koolist välja langeda kui nende vähem ükskõiksetel eakaaslastel (Bask \& Salmela-Aro, 2013). Läbipõlemise tõsidusele ja aktuaalsusele Eestis viitab asjaolu, et kuigi nende õpilaste osakaal, kes ei pea kooliskäimist meeldivaks, on langustrendis, siis koolitööd pingeliseks pidavate õpilaste osakaal on võrreldes varasemate aastatega kasvanud (Aasvee et al., 2016).

Uuringud heaolu ja vaimse tervise vallast osutavad, et kultuuritaust võib olla seotud stressi reguleerimiseks kasutatavate toimetulekumehhanismide ja -ressursside eripäradega, aga ka motivatsiooniteguritega. Samuti on leitud, et keelesüsteem, varieerudes kultuuriti, võib olla seotud sellega, kuidas indiviidid keskkonda tõlgendavad ja sellele reageerivad. (Leighton \& Hughes, 2005; Marsella, 2010) Seda arvesse võttes seadsime uurimuse peamiseks eesmärgiks analüüsida 8. klasside eesti ja vene õppekeelega õpilaste läbipõlemist ning läbipõlemise seoseid erinevate kognitiivsete ja sotsiaal-kognitiivsete teguritega, täpsemalt matemaatikaoskuste, üldvõimekuse, arenguuskumuste ja säilenõtkusega.

Erinevused läbipõlemises. Vastusena esimesele uurimisküsimusele, mis käsitles erinevusi eesti ja vene õppekeelega õpilaste enesekohastes hinnangutes oma läbipõlemisele, näitavad tulemused, et läbipõlemisele viitavate sümptomite kogemine on valimisse kuulunud 8. klassi õpilaste hulgas pigem tavapärane: enamik õpilasi on enda hinnangul tundnud läbipõlemisele viitavaid sümptomeid. Siiski, kui varasemad uurimistulemused on näidanud, et võrreldes vene koolide õpilastega on eesti õppekeelega koolide õpilased õppimisega vähem rahul ning tunnetavad enam ülekoormatust ja eelkõige ükskõiksust (Kikas, Jõgi et al., 2016), siis meie tulemused näitasid, et eesti ja vene õppekeelega koolide õpilaste läbipõlemise näitajad olid sarnased. Erinevus varasemate tulemustega võib osaliselt olla tingitud valimi eripärast: praeguses uuringus osalesid ainult Tallinna koolid ja valimi maht oli piiratud $(N=429)$. On võimalik, et 2016. aastal tehtud matemaatika taustauuringu (Kikas, Jõgi et al., 2016) suure valimi korral võisid väikesed erinevused olla võimendatud, kuid sama võimalik on ka see, et praeguse uuringu väiksem valim ei võimaldanud üldkogumis tegelikult eksisteerivaid erinevusi piisavalt esile tuua. Sellegipoolest võib arvata, et erinevused eesti ja vene õppekeelega õpilaste läbipõlemise tasemes, kui need ka esinevad, on pigem väikesed.

Kognitiivsed tegurid läbipõlemise ennustajatena. Kuna meid huvitas, mis tegurid võiksid läbipõlemisega kõige enam seostuda, käsitles teine uurimisküsimus kognitiivsete ja sotsiaal-kognitiivsete tegurite rolli läbipõlemise ennustamisel eri õppekeelega rühmades. Kuigi varasemad uurimistulemused osutavad, et läbipõlemine on oluliselt seotud halvemate akadeemiliste tule- 
mustega (Kiuru, Aunola, Nurmi, Leskinen, \& Salmela-Aro, 2008; May et al., 2015; Salmela-Aro et al., 2008; Tuominen-Soini \& Salmela-Aro, 2014), siis meie uuringus ei olnud ei eesti ega vene õppekeelega õpilaste matemaatikaoskused ega üldvõimekus läbipõlemisega oluliselt seotud. Oletatavalt on lahknevus varasematest uurimistulemustest tingitud asjaolust, et siinses uurimuses oleme akadeemilise sooritusena käsitlenud mitte tavapäraselt kasutatavat hinnangut õpilase akadeemilisele sooritusele (keskmine hinne), vaid puhast sooritust ehk matemaatikatesti ja üldvõimekuse testi tulemusi. Ehkki akadeemiline sooritus, kui see on juba vahendatud sotsiaalsetest hinnangutest, mida hinded paratamatult on, võib küll olla oluline läbipõlemise ennustaja, osutab praegune uuring, et puhas üldvõimekus või akadeemilised oskused läbipõlemist ei ennusta - kehvem akadeemiline võimekus ei ole otseselt seotud kõrgema läbipõlemismääraga ning läbipõlemisele viitavaid sümptomeid esineb nii võimekatel kui ka vähem võimekatel õpilastel.

Sotsiaal-kognitiivsed tegurid läbipõlemise ennustajana. Erinevalt kognitiivsetest teguritest ennustasid meie uurimuses läbipõlemist oluliselt just sotsiaalkognitiivsete protsesside ja emotsionaalse toimetulekuga seotud tegurid ning seda nii eesti kui ka vene õppekeelega õpilaste hulgas. Täpsemalt avaldus mõlemas rühmas selge seos nii jäävususkumustele kaldumise ja sügavama läbipõlemise kui ka madalama säilenõtkuse taseme ja tugevamalt ilmneva läbipõlemise vahel. Teisisõnu, suurema tõenäosusega on läbipõlemisele viitavad sümptomid neil õpilastel, kes kalduvad arvama, et võimekus on pigem muutumatu ja õppimine peaks toimuma kergelt-kiirelt, ning neil õpilastel, kes ei tule hästi toime koolielu igapäevaste ebaõnnestumistega. Ka varasemad uurimistulemused näitavad, et jäävususkumustega õpilastel on kõrgem kooliga seotud stressitase (Yeager et al., 2014), mida on omakorda seostatud läbipõlemisega (SalmelaAro, Savolainen et al., 2009). Samuti on läbipõlemise ja säilenõtkuse vahelise olulise seose ilmnemine kooskõlas varasemate uurimistulemustega (nt GarciaIzquierdo et al., 2018; Guo et al., 2018; Richards et al., 2016).

Arenguuskumused ja nende toetamine. Kuna eesti ja vene õppekeelega õpilaste jäävususkumuste tasemes ei ilmnenud erinevusi ning mõlemas keelerühmas avaldus jäävususkumuste tugev seos läbipõlemisega, leidis kinnitust üldisem idee, et jäävususkumused avalduvad kooliõpilaste hulgas kultuurideüleselt ning seostuvad kehvema heaoluga (Yeager \& Dweck, 2012; Zeng et al., 2016). Sotsiaal-emotsionaalseid oskusi, sh sotsiaal-konstruktivistlike tõlgendustega läbi põimunud oskusi, saab õpetamise kaudu arendada ning sellel on positiivne mõju teismeliste toimetulekule igapäevase sotsiaalse stressiga (Yeager, Lee, \& Jamieson, 2016) ja säilenõtkuse parandamisele (Yeager \& Dweck, 2012), mis omakorda väljendub paremates õpitulemustes (Yeager et al., 2016). Eri ülevaateuurimustes rõhutatakse, et koolid ja õpetajad peaksid pöö- 
rama enam tähelepanu ebatõhusatele uskumustele klassiruumis (Haimovitz \& Dweck, 2016; Yeager \& Dweck, 2012), võimaldama õpilastel õpivõimalusi paremini märgata ja ära kasutada (Yeager \& Walton, 2011) ning pakkuma õpilastele nende potentsiaali realiseerimiseks vajalikke oskusi, vahendeid ja sobivat keskkonda (Yeager \& Dweck, 2012).

Säilenõtkus ja selle toetamine. Meie uurimistulemustest ilmnev seos säilenõtkuse ja läbipõlemise vahel kinnitab varasemaid tulemusi, mis viitavad, et säilenõtkus on kaitsefaktor (Dray et al., 2017; Garcia-Izquierdo et al., 2018), mille olulisust ja arendatavust on rõhutatud eri uurimustes (nt GarciaIzquierdo et al., 2018; Masten, 2001). Samuti osutavad uurimused vajadusele arendada säilenõtkust teadlikult, et säilitada või parandada õpilaste psühholoogilist heaolu (Dray et al., 2017; Fenwick-Smith, Dahlberg, \& Thompson, 2018; Garcia-Izquierdo et al., 2018). Õpilaste vaimse tervise probleemide ennetamiseks ja vähendamiseks ning säilenõtkuse suurendamiseks on välja töötatud ka selliseid sekkumisprogramme, mida saab siduda eri õppekavadega (vt nt Fenwick-Smith et al., 2018) ning mille puhul on tõendatud positiivne mõju õpilaste igapäevaste stressitekitajatega toimetuleku oskustele. Õpetajad ja hariduslik tugipersonal saavad õpilaste säilenõtkuse toetamiseks mõndagi ära teha. Näiteks on abi ülesannete individualiseerimisest, planeerimisoskuse ja püsivuse toetamisest ning konstruktiivsest tagasisidest, mis ei rõhuta võistlemist kaaslastega (Garcia-Izquierdo et al., 2018). Säilenõtkusega on seostatud ka uute strateegiate otsimist, suuremat pingutust ja konfliktide rahumeelset lahendamist (Yeager \& Dweck, 2012). Kirjeldatud võtteid saab siduda õppekava tavapäraste tegevustega ja nende rakendamiseks ei ole tingimata vaja kaasata spetsialiste (Garcia-Izquierdo et al., 2018).

Seosed läbipõlemise ja sotsiaal-kognitiivsete tegurite vahel eri võimekusega ópilaste rühmades ning eri óppekeelte puhul. Kolmas uurimisküsimus käsitles arenguuskumuste ja säilenõtkuse ning läbipõlemise vahelisi seoseid eesti ja vene õppekeelega õpilaste hulgas eri võimekusega rühmades. Leidsime, et ehkki mõlema keelerühma korral on kõrge säilenõtkuse tase seotud madalama läbipõlemise tasemega kõigis matemaatikaoskuste rühmades, ilmnes oluliselt tugevam seos säilenõtkuse ja läbipõlemise vahel kõige paremate matemaatikaoskustega ning just eesti õppekeelega õpilastel. Teisisõnu, teatud õpilasrühmades võib akadeemiline edukus ennustada madala sotsiaal-kognitiivsete oskuste taseme puhul pigem pärsitud heaolu. Ka varem on uurimistulemused vihjanud võimalusele, et head tulemused, kui nendega kaasneb näiteks liigne tulemusele orienteeritus, võivad seostuda kehvema psühholoogilise heaolu ja suurema ärevusega (vt nt Kaplan \& Maehr, 2007). Sama kinnitavad Soomes tehtud uuringud: ka edukad õpilased võivad olla altid läbipõlemisele, kui neil on kõrge depressiivsete sümptomite ja stressitase (Salmela-Aro et al., 2018; 
Tuominen-Soini \& Salmela-Aro, 2014). Ilmnenud seose täpsem kirjeldamine ja mõistmine on oluline edasine uurimisteema. Põhjalikum ja võimalik et ka osaliselt kvalitatiivne analüüs aitaks paremini mõista eesti ja vene õppekeelega õpilaste säilenõtkuse tagamaid.

Uuringu piirangud ja ettepanekud edasiseks uurimistööks. Uuringul on ka mitu piirangut. Esiteks oli tegu ristläbilõikelise uuringuga ning seega ei saa teha järeldusi ilmnenud seoste põhjuslikkuse kohta. Teiseks oli valim suhteliselt väike ja uuringusse olid kaasatud vaid Tallinna koolid. See võib seada piiranguid tulemuste üldistatavusele, eriti veel kontekstis, kus tulemused viitavad olulistele erinevustele kahe uuritud rühma vahel. Seetõttu soovitame tulemuste üldistamisel olla ettevaatlik ning peame vajalikuks käsitleda teemat põhjalikumalt edasi, kasutades suuremaid valimeid ning täiustatud hindamismetoodikat. Samuti tuleb uurimistulemuste tõlgendamisel silmas pidada, et uurimuses ei kasutatud kõiki originaalskaalade väiteid: kuna uurimuses oli kesksel kohal rühmade võrreldavus, siis kasutasime ainult neid väiteid, mis võimaldasid uuritavaid rühmi usaldusväärselt võrrelda. Kuna uuringute järgi jääb igapäevaste uute raskuste ilmnemisel lühiajaliste sekkumisprogrammide mõju nõrgaks (nt Donohoe, Topping, \& Hannah, 2012; Yeager \& Walton, 2011), vajame peale täiustatud mõõtevahendite ka täpselt kavandatud sekkumisuuringuid, mis pakuvad võimaluse uurida arenguuskumuste ja säilenõtkuse toetamise mõju nii eraldi kui ka kombineeritult õpilaste heaolu ja akadeemilise edukuse kontekstis.

\section{Tänusõnad}

Uuringu tegemist on toetanud Haridus- ja Teadusministeerium. Täname professor Eve Kikase uurimisrühma ning kõiki uuringus osalenud õpilasi ja õpetajaid.

\section{Kasutatud kirjandus}

Aasvee, K., Liiv, K., Eha, M., Oja, L., Härm, T., \& Streimann, K. (2016). Eesti kooliópilaste tervisekäitumine: 2013/2014. óppeaasta uuringu raport. Tallinn: Tervise Arengu Instituut.

Bask, M., \& Salmela-Aro, K. (2013). Burned out to drop out: Exploring the relationship between school burnout and school dropout. European Journal of Psychology of Education, 28(2), 511-528. https://doi.org/10.1007/s10212-012-0126-5

Blackwell, L. S., Trzesniewski, K. H., \& Dweck, C. S. (2007). Implicit theories of intelligence predict achievement across an adolescent transition: A longitudinal study and an intervention. Child Development, 78(1), 246-263.

https://doi.org/10.1111/j.1467-8624.2007.00995.x 
Boekaerts, M., \& Niemivirta, M. (2000). Self-regulated learning: Finding a balance between learning goals and ego-protective goals. In M. Boekaerts, P. R. Pintrich, \& M. Zeidner (Eds.), Handbook of self-regulation (pp. 417-450). San Diego: Academic Press. https://doi.org/10.1016/B978-012109890-2/50042-1

Borman, G. D., \& Overman, L. T. (2004). Academic resilience in mathematics among poor and minority students. Elementary School Journal, 104(3), 177-195. https://doi.org/10.1086/499748

Buecker, S., Nuraydin, S., Simonsmeier, B. A., Schneider, M., \& Luhmann, M. (2018). Subjective well-being and academic achievement: A meta-analysis. Journal of Research in Personality, 74, 83-94. https://doi.org/10.1016/j.jrp.2018.02.007

Carey, E., Hill, F., Devine, A., \& Szücs, D. (2017). The Modified Abbreviated Math Anxiety Scale: A valid and reliable instrument for use with children. Frontiers in Psychology, 8. https://doi.org/10.3389/fpsyg.2017.00011

Cassidy, S. (2016). The Academic Resilience Scale (ARS-30): A new multidimensional construct measure. Frontiers in Psychology, 7. https://doi.org/10.3389/fpsyg.2016.01787

Cheung, G. W., \& Rensvold, R. B. (2002). Evaluating goodness-of-fit indexes for testing measurement invariance. Structural Equation Modeling: A Multidisciplinary Journal, 9(2), 233-255. https://doi.org/10.1207/S15328007SEM0902_5

Council Recommendation (2018). Council recommendation on key competences for lifelong learning. ST 90092018 INIT. Brussels: Council of the European Union.

Donohoe, C., Topping, K., \& Hannah, E. (2012). The impact of an online intervention (brainology) on the mindset and resiliency of secondary school pupils: A preliminary mixed methods study. Educational Psychology, 32(5), 641-655. https://doi.org/10.1080/01443410.2012.675646

Dray, J., Bartlem, K., Bowman, J., Bailey, J., Campbell, E., Wolfenden, L., ... Palazzi, K. (2017). Systematic review of universal resilience-focused interventions targeting child and adolescent mental health in the school setting. Journal of the American Academy of Child and Adolescent Psychiatry, 56(10), 813-824.

https://doi.org/10.1016/j.jaac.2017.07.780

Dweck, C. S., Chiu, C. S., \& Hong, Y. Y. (1995). Implicit theories and their role in judgments and reactions: A word from two perspectives. Psychological Inquiry, 6(4), 267-285. https://doi.org/10.1207/s15327965pli0604_1

Dweck, C. S., \& Leggett, E. L. (1988). A social-cognitive approach to motivation and personality. Psychological Review, 95(2), 256-273. https://doi.org/10.1037/0033-295X.95.2.256

Eesti elukestva õppe strateegia 2020 (2014). Tallinn: Haridus- ja Teadusministeerium. Külastatud aadressil https://www.hm.ee/sites/default/files/strateegia2020.pdf.

Eesti Statistikaamet (2018). Statistika andmebaas. RV0222: Rahvastik soo, rahvuse ja maakonna järgi. Külastatud aadressil http://andmebaas.stat.ee/Index.aspx?lang=et\&DataSetCode=RV0222.

Efklides, A. (2011). Interactions of metacognition with motivation and affect in selfregulated learning: The MASRL model. Educational Psychologist, 46(1), 6-25. https://doi.org/10.1080/00461520.2011.538645 
Fenwick-Smith, A., Dahlberg, E. E., \& Thompson, S. C. (2018). Systematic review of resilience-enhancing, universal, primary school-based mental health promotion programs. BMC Psychology, 6(1), 6-30.

https://doi.org/10.1186/s40359-018-0242-3

Garcia-Izquierdo, M., Rios-Risquez, M., Carrillo-Garcia, C., \& de los Angeles Sabuco-Tebar, E. (2018). The moderating role of resilience in the relationship between academic burnout and the perception of psychological health in nursing students. Educational Psychology, 38(1), I-XIII.

Garnefski, N., Legerstee, J., Kraaij, V., van den Kommer, T., \& Teerds, J. (2002). Cognitive coping strategies and symptoms of depression and anxiety: A comparison between adolescents and adults. Journal of Adolescence, 25(6), 603-611. https://doi.org/10.1006/jado.2002.0507

Guo, Y.-F., Luo, Y.-H., Lam, L., Cross, W., Plummer, V., \& Zhang, J.-P. (2018). Burnout and its association with resilience in nurses: A cross-sectional study. Journal of Clinical Nursing, 27(1/2), 441-449. https://doi.org/10.1111/jocn.13952

Haimovitz, K., \& Dweck, C. S. (2016). Parents' views of failure predict children's fixed and growth intelligence mind-sets. Psychological Science, 27(6), 859-869. https://doi.org/10.1177/0956797616639727

HKS 2014 = Erelt, T., Kadakas, M., Kala-Arvisto, U., Kraav, I., Maanso, V., Puksand, H., Tamm, E., \& Unt, I. (toim) (2014). Säilenõtkus. T. Erelt (toim), Hariduse ja kasvatuse sõnaraamat (lk 398). Tallinn: Eesti Keele Sihtasutus.

Inglehart, R., \& Klingemann, H. D. (2000). Genes, culture, democracy, and happiness. In E. Diener \& E. M. Suh (Eds.), Culture and subjective well-being (pp. 185218). Cambridge: MIT Press.

Johnsen, A., Ortiz-Barreda, G., Rekkedal, G., \& Iversen, A. C. (2017). Minority children and academic resilience in the Nordic welfare states. International Journal of Migration, Health and Social Care, 13(4), 374-390.

https://doi.org/10.1108/IJMHSC-11-2015-0050

Kaplan, A., \& Maehr, M. L. (2007). The contributions and prospects of goal orientation theory. Educational Psychology Review, 19(2), 141-184. https://doi.org/10.1007/s10648-006-9012-5

Kikas, E., Aus, K., Kaldoja, M-L., Arro, G., Kivi, V., \& Luptova, O. (2016). Õpetajate toetamine üldpädevuste arendamisel - intensiivkoolitusest ja selle tulemustest. Artiklid üldpädevustest (lk 89-97). Külastatud aadressil https://oppekava.innove. ee/wp-content/uploads/sites/6/2017/03/Yldpadevuste_kontsept.pdf.

Kikas, E., Jõgi, A.-L., Palu, A., Mädamürk, K., \& Luptova, O. (2016). Põhikooli matemaatika lõpueksami tausta uuringu tulemused: aruanne. Tallinn: Innove.

Kiuru, N., Aunola, K., Nurmi, J.-E., Leskinen, E., \& Salmela-Aro, K. (2008). Peer group influence and selection in adolescents' school burnout: A longitudinal study. Merrill-Palmer Quarterly, 54(1), 23-55.

https://doi.org/10.1353/mpq.2008.0008

Lei, P.-W., \& Wu, Q. (2007). Introduction to structural equation modeling: Issues and practical considerations. Educational Measurement: Issues \& Practice, 26(3), 33-43. https://doi.org/10.1111/j.1745-3992.2007.00099.x

Leighton, A. H., \& Hughes, J. M. (2005). Cultures as a causative of mental disorder. The Milbank Quarterly, 83(4), 1-22.

https://doi.org/10.1111/j.1468-0009.2005.00424.x 
Liston, C., McEwen, B. S., \& Casey, B. J. (2009). Psychosocial stress reversibly disrupts prefrontal processing and attentional control. Proceedings of the National Academy of Sciences of the United States of America, 106(3), 912-917.

https://doi.org/10.1073/pnas.0807041106

Marsella, A. J. (2010). Ethnocultural aspects of PTSD: An overview of concepts, issues, and treatments. Traumatology, 16(4), 17-26. https://doi.org/10.1177/1534765610388062

Marsella, A. J., \& Yamada, A. M. (2010). Culture and psychopathology: Foundations, issues, and directions. In S. Kitayama \& D. Cohen (Eds.), Handbook of cultural psychology (pp. 103-115). New York: Guilford Press.

Martin, A. J., \& Marsh, H. W. (2006). Academic resilience and its psychological and educational correlates: A construct validity approach. Psychology in the Schools, 43(3), 267-281. https://doi.org/10.1002/pits.20149

Maslach, C. (2003). Burnout assessment. In R. Fernandez-Ballesteros (Ed.), Encyclopedia of Psychological Assessment (Vol. 1 A-M, pp. 150-154). London, Thousand Oaks, New Delhi: SAGE Publications.

Maslach, C., \& Jackson, S. E. (1981). The measurement of experienced burnout. Journal of Occupational Behaviour, 2, 99-113. https://doi.org/10.1002/job.4030020205

Masten, A. S. (2001). Ordinary magic. Resilience processes in development. The American Psychologist, 56(3), 227-238. https://doi.org/10.1037/0003-066X.56.3.227

Masten, A. S., Best, K. M., \& Garmezy, N. (1990). Resilience and development: Contributions from the study of children who overcome adversity. Development and Psychopathology, 2(4), 425-444. https://doi.org/10.1017/S0954579400005812

May, R. W., Bauer, K. N., \& Fincham, F. D. (2015). School burnout: Diminished academic and cognitive performance. Learning and Individual Differences, 42, 126131. https://doi.org/10.1016/j.lindif.2015.07.015

Mõttus, R. (2010). Tarkus toob tervise ja pika elu: inimestevaheliste psühholoogiliste erinevuste tähendusest meditsiinis. Eesti Arst, 89(5), 330-338.

Mõttus, R., Allik, J., \& Realo, A. (2011). Intelligentsuse psühholoogia. Tartu: Tartu Ülikooli Kirjastus.

OECD (2017). PISA 2015 results (Vol. III): Students' well-being. Paris: OECD Publishing.

OECD (2018). The resilience of students with an immigrant background: Factors that shape well-being, OECD reviews of migrant education. Paris: OECD Publishing.

Okas, R. (2014). Üliõpilaste saavutuseesmärgid, õppimisstrateegiad, läbipõlemine ja nende seosed õpitulemustega (magistritöö). Tallinn: Tallinna Ülikool.

Ots, A. (2014). Ôpilaste heaolu resilientsus ja mõistestruktuuri areng: erinevused kooliga rahulolu säilitamisel ebameeldivate koolikogemuste ja klassiõpetaja kasvatusstiili taustal. Eesti Haridusteaduste Ajakiri, 2(1), 132-161. https://doi.org/10.12697/eha.2014.2.1.06

Panadero, E. (2017). A review of self-regulated learning: Six models and four directions for research. Frontiers in Psychology, 8.

https://doi.org/10.3389/fpsyg.2017.00422 
Pintrich, P. R. (2000). The role of goal orientation in self-regulated learning. In M. Boekaerts, P. R. Pintrich, \& M. Zeidner (Eds.), Handbook of self-regulation (pp. 451-502). San Diego: Academic Press. https://doi.org/10.1016/B978-012109890-2/50043-3

PISA (2018). PISA: koduleht. Haridus- ja Teadusministeerium. Külastatud aadressil https://www.hm.ee/et/tegevused/uuringud-ja-statistika/pisa.

Põhikooli riiklik õppekava (2018). Riigi Teataja, RT I, 14.01.2011, 1; RT I, 14.02.2018, 8. Külastatud aadressil https://www.riigiteataja.ee/akt/114022018008.

Raven, J. (1981). Manual for Raven's progressive matrices and mill hill vocabulary scales. Oxford: Oxford Psychologists Press.

Richards, K. A., Levesque-Bristol, C., Templin, T. J., \& Graber, K. C. (2016). The impact of resilience on role stressors and burnout in elementary and secondary teachers. Social Psychology of Education, 19(3), 511-536. https://doi.org/10.1007/s11218-016-9346-X

Rohde, T. E., \& Thompson, L. A. (2007). Predicting academic achievement with cognitive ability. Intelligence, 35(1), 83-92. https://doi.org/10.1016/j.intell.2006.05.004

Rosseel, Y. (2012). lavaan: An R package for structural equation modeling. Journal of Statistical Software, 48(2), 1-36. https://doi.org/10.18637/jss.v048.i02

Salmela-Aro, K., Kiuru, N., \& Jokela, J. (2008). Does school matter? The role of school context in adolescents' school-related burnout. European Psychologist, 13(1), 12-23. https://doi.org/10.1027/1016-9040.13.1.12

Salmela-Aro, K., Kiuru, N., Leskinen, E., \& Nurmi, J.-E. (2009). School burnout inventory (SBI) reliability and validity. European Journal of Psychological Assessment, 25(1), 48-57. https://doi.org/10.1027/1015-5759.25.1.48

Salmela-Aro, K., Read, S., Minkkinen, J., Kinnunen, J. M., \& Rimpela, A. (2018). Immigrant status, gender, and school burnout in Finnish lower secondary school students: A longitudinal study. International Journal of Behavioral Development, 42(2), 225-236. https://doi.org/10.1177/0165025417690264

Salmela-Aro, K., Savolainen, H., \& Holopainen, L. (2009). Depressive symptoms and school burnout during adolescence: Evidence from two cross-lagged longitudinal studies. Journal of Youth and Adolescence, 38(10), 1316-1327. https://doi.org/10.1007/s10964-008-9334-3

Schaufeli, W. B., Martinez, I. M., Pinto, A. M., Salanova, M., \& Bakker, A. B. (2002). Burnout and engagement in university students: A cross-national study. Journal of Cross-Cultural Psychology, 33(5), 464-481.

https://doi.org/10.1177/0022022102033005003

Schommer-Aikins, M., Mau, W.-C., Hutter, R., \& Brookhart, S. (2000). Understanding middle students' beliefs about knowledge and learning using a multidimensional paradigm. Journal of Educational Research, 94(2), 120-127. https://doi.org/10.1080/00220670009598750

Soll, M., Salvet, S., \& Masso, A. (2015). Changes in language policy in Estonia: Selfdescriptions of Russian-speaking students. TRAMES: A Journal of the Humanities \& Social Sciences, 19(3), 221-247. https://doi.org/10.3176/tr.2015.3.02

Strenze, T. (2007). Intelligence and socioeconomic success: A meta-analytic review of longitudinal research. Intelligence, 35(5), 401-426.

https://doi.org/10.1016/j.intell.2006.09.004 
Zeng, G., Peng, K., \& Hou, H. (2016). Effect of growth mindset on school engagement and psychological well-being of Chinese primary and middle school students: The mediating role of resilience. Frontiers in Psychology, 7. https://doi.org/10.3389/fpsyg.2016.01873

Zimmerman, B. J. (2000). Attaining self-regulation: A social cognitive perspective. In M. Boekaerts, P. R. Pintrich, \& M. Zeidner (Eds.), Handbook of self-regulation (pp. 13-39). San Diego: Academic Press. https://doi.org/10.1016/B978-012109890-2/50031-7

Taub, G. E., Keith, T. Z., Floyd, R. G., \& McGrew, K. S. (2008). Effects of general and broad cognitive abilities on mathematics achievement. School Psychology Quarterly, 23(2), 187-198. https://doi.org/10.1037/1045-3830.23.2.187

Tuominen-Soini, H., \& Salmela-Aro, K. (2014). Schoolwork engagement and burnout among Finnish high school students and young adults: Profiles, progressions, and educational outcomes. Developmental Psychology, 50(3), 649-662. https://doi.org/10.1037/a0033898

Van de Schoot, R., Lugtig, P., \& Hox, J. (2012). A checklist for testing measurement invariance. European Journal of Developmental Psychology, 9(4), 486-492. https://doi.org/10.1080/17405629.2012.686740

Vasalampi, K., Salmela-Aro, K., \& Nurmi, J.-E. (2009). Adolescents's self-concordance, school engagement, and burnout predict their educational trajectories. European Psychologist, 14(4), 332-341. https://doi.org/10.1027/1016-9040.14.4.332

Wang, J., \& Wang, X. (2012). Structural equation modeling: Applications using Mplus. Chichester: Wiley \& Higher Education Press.

https://doi.org/10.1002/9781118356258

Yeager, D. S., \& Dweck, C. S. (2012). Mindsets that promote resilience: When students believe that personal characteristics can be developed. Educational Psychologist, 47(4), 302-314. https://doi.org/10.1080/00461520.2012.722805

Yeager, D. S., Johnson, R., Spitzer, B. J., Trzesniewski, K. H., Powers, J., \& Dweck, C. S. (2014). The far-reaching effects of believing people can change: Implicit theories of personality shape stress, health, and achievement during adolescence. Journal of Personality and Social Psychology, 106(6), 867-884. https://doi.org/10.1037/a0036335

Yeager, D. S., Lee, H. Y., \& Jamieson, J. P. (2016). How to improve adolescent stress responses: Insights from integrating implicit theories of personality and biopsychosocial models. Psychological Science, 27(8), 1078-1091.

https://doi.org/10.1177/0956797616649604

Yeager, D. S., \& Walton, G. M. (2011). Social-psychological interventions in education: They're not magic. Review of Educational Research, 81(2), 267-301. https://doi.org/10.3102/0034654311405999

Yu, L., Shek, D. T. L., \& Zhu, X. (2018). The influence of personal well-being on learning achievement in university students over time: Mediating or moderating effects of internal and external university engagement. Frontiers in Psychology, 8. https://doi.org/10.3389/fpsyg.2017.02287 


\title{
Academic burnout among Estonian and Russian middle school students
}

\author{
Kati Vinter ${ }^{\text {al }}$, Kati Aus ${ }^{\mathrm{a}}$, Grete Arro ${ }^{\mathrm{a}}$ \\ ${ }^{a}$ School of Educational Sciences, Tallinn University
}

\begin{abstract}
Summary
Different documents and research that guides educational policy at the national level (Eesti elukestva õppe strateegia 2020, 2014) as well as in the European Union (Council Recommendation, 2018; OECD, 2017, 2018) stress the importance of guiding skills that help sustain students' psychological well-being. In order to meet the demands to support students' social-emotional needs, Estonia has introduced the concept of general competencies into its National Curriculum (Põhikooli riiklik õppekava, 2018). The theoretical frameworks of self-regulated learning also clearly state the importance of cognitive, metacognitive, behavioral, motivational and social-emotional aspects that are essential to support the development of students who are in control of their learning and well-being (e.g., Boekaerts \& Niemivirta, 2000; Efklides, 2011; Pintrich, 2000; Zimmerman, 2000; for a review see also Panadero, 2017).

The importance of well-being is also supported by the fact that it serves as an important foundation for building academic skills (Buecker et al., 2018) and staying on the educational track (Bask \& Salmela-Aro, 2013). It has been found that subjective well-being is an important predictor of students' personal development as well as their academic success (Yu et al., 2018). A lack of emotional well-being can manifest itself in feelings of academic burnout (SalmelaAro, Savolainen et al., 2009) that has been associated with adolescents' poor achievement (Salmela-Aro et al., 2008; Salmela-Aro, Savolainen, et al., 2009) as well as dropping out of school (Bask \& Salmela-Aro, 2013). Most adolescents cope with their teenage years without any serious emotional problems but there is still a considerable group of youngsters who struggle to cope with the changes of this transition period (Blackwell et al., 2007; Salmela-Aro, Savolainen et al., 2009). For this reason it is important to study the factors behind the decline of well-being in teenagers, and focus attention on the possible risk factors leading to burnout.
\end{abstract}

School of Educational Sciences, Tallinn University, Narva mnt 25, 10120 Tallinn, Estonia; kati.vinter@tlu.ee 
Academic burnout comprises of three sub dimensions: exhaustion because of school demands, cynicism toward the meaning of school and feelings of inadequacy as a student (Salmela-Aro et al., 2008; Salmela-Aro, Kiuru et al., 2009; Salmela-Aro, Savolainen et al., 2009). However, in Estonian, as the word 'cynicism' does not reflect the actual content of the measured items we used the word 'indifference' instead of 'cynicism'.

Studying academic burnout in middle school has received little attention in Estonia (see Kikas, Jõgi et al., 2016) although there is reason to believe that the problem is becoming more evident. Although it has been documented that there are a decreasing number of students who regard going to school as unpleasant, the number of students who feel that their school-work is stressful, is on the rise (Aasvee et al., 2016).

Today's Estonia is a multiethnic society, comprising 69\% Estonians and 25\% Russians (Eesti Statistikaamet, 2018), and has a unique educational system where Estonian and Russian language schools operate side by side (Soll et al., 2015). Whereas differences between those language-groups have been studied in regard to academic results, less research has focused on differences and similarities in the emotional well-being and social-cognitive functioning of the two groups (but see Aasvee et al., 2016; Kikas, Jõgi et al., 2016; PISA, 2018). Also, work carried out on the adaptation of relevant measurement instruments is still scarce. As we cannot assume that the constructs assessed as well as the instruments used are universal across cultures (Marsella \& Yamada, 2010) and it has been demonstrated that cultural factors as well as our language system, that is deeply cultural, determines the way individuals interpret their environment and organise their responses to that environment (Leighton \& Hughes, 2005; Marsella, 2010), instruments that are used for assessing social-cognitive aspects of functioning, call for detailed analysis.

Hence, in the current study we aimed to study academic burnout of Estonian and Russian speaking eighth-graders in Estonia and analyse the associations between burnout and the students' ethnic background and cognitive abilities as well as beliefs and attributions supporting or hindering their well-being and coping. We measured academic burnout (Salmela-Aro, Kiuru et al., 2009) as a single factor construct since the three sub dimensions correlated strongly, even in one case demonstrating multicollinearity. The cognitive factors in the study were academic achievement as measured by the math ability test and general cognitive ability as measured by Raven progressive matrices. The social-cognitive factors we chose to study in more detail, as possible predictors of academic burnout, were the students' implicit ability beliefs or mindsets (Dweck et al., 1995; Schommer-Aikins et al., 2000) and academic psychological 
buoyancy (Martin \& Marsh, 2006). At the same time we focused on assessing the measurement invariance of the instruments in the two language-groups.

The sample consisted of 429 eighth-graders from five Russian $(n=174)$ and seven Estonian ( $n=255)$ language schools. We used confirmatory factor analysis and measurement invariance analysis for assessing the validity and reliability of the measurement instruments. Analysis of variance and regression analysis were used to analyse differences in the burnout levels and associations with other variables.

We found that experiencing symptoms associated with burnout is common: most students reported having felt burnout symptoms associated with their studies. Whereas earlier studies have shown that when compared to their Russian-speaking peers, Estonian students were less satisfied with their schoolwork and reported feeling more exhaustion and indifference (Kikas, Jõgi et al., 2016), our results attested to similar levels of burnout in schools with Estonian and Russian study-language.

We were also interested in cognitive and social-cognitive factors that were significantly associated with burnout. In both language groups we found that neither math skills nor general ability were associated with burnout. This seems to contradict with earlier research (Kiuru et al., 2008; May et al., 2015; SalmelaAro et al., 2008; Tuominen-Soini \& Salmela-Aro, 2014), but as we used pure cognitive ability measured by cognitive tests as opposed to GPA, our results clarify earlier results and point to the fact that burnout can be experienced by students at all levels of intellectual ability.

Although cognitive factors failed to predict burnout in both language groups, the social-cognitive components played significant roles for both Estonian and Russian students. More precisely, we found a significant association with ability beliefs as well as academic psychological buoyancy. Higher levels of academic burnout were predicted by entity (fixed) beliefs of ability for Estonian and for the Russian sample and lower psychological buoyancy. Suggesting that, students who tend to regard intelligence as something fixed and students who have trouble with bouncing back from everyday difficulties or failures are more likely to experience symptoms of academic burnout.

We were also interested in assessing the predictive power of social-cognitive factors in different ability groups. It appeared that although lower psychological buoyancy was associated with higher levels of burnout at all levels of ability in both language groups, the association was strongest in Estonian students with high math ability. It has previously been noted that high achievement when accompanied with less adaptive social-emotional functioning, like high performance orientation or high levels of stress and depression symptoms, might 
be associated with poor psychological health and higher levels of burnout or anxiety (e.g., Kaplan \& Maehr, 2007; Tuominen-Soini \& Salmela-Aro, 2014).

Further studies should focus on developing the knowledge and skills of implicit ability beliefs as well as psychological buoyancy among middle school students.

\section{Acknowledgements}

The research was supported by the Estonian Ministry of Education and Research.

Keywords: academic burnout, math skills, general cognitive ability, implicit ability beliefs, academic psychological buoyancy, Estonian and Russian studylanguage 